\title{
DIGITALCOMMONS
}

@WAYNESTATE —

Wayne State University

$12-15-2020$

\section{Molecular Variation of Rh, MN, Duffy, Kidd, Kell, and Lutheran Blood Groups in the Human Population of Bosnia and Herzegovina}

\author{
Lejla Lasic \\ University of Sarajevo \\ Abdurahim Kalajdzic \\ University of Sarajevo \\ Belma Kalamujic Stroil \\ University of Sarajevo \\ Lejla Pojskic \\ University of Sarajevo \\ Jasna Hanjalic \\ University of Sarajevo
}

See next page for additional authors

Follow this and additional works at: https://digitalcommons.wayne.edu/humbiol_preprints

\section{Recommended Citation}

Lasic, Lejla; Kalajdzic, Abdurahim; Kalamujic Stroil, Belma; Pojskic, Lejla; Hanjalic, Jasna; Usanovic, Lejla; and Pojskic, Naris, "Molecular Variation of Rh, MN, Duffy, Kidd, Kell, and Lutheran Blood Groups in the Human Population of Bosnia and Herzegovina" (2020). Human Biology Open Access Pre-Prints. 179. https://digitalcommons.wayne.edu/humbiol_preprints/179

This Article is brought to you for free and open access by the WSU Press at DigitalCommons@WayneState. It has been accepted for inclusion in Human Biology Open Access Pre-Prints by an authorized administrator of DigitalCommons@WayneState. 


\section{Authors}

Lejla Lasic, Abdurahim Kalajdzic, Belma Kalamujic Stroil, Lejla Pojskic, Jasna Hanjalic, Lejla Usanovic, and Naris Pojskic 
Molecular Variation of Rh, MN, Duffy, Kidd, Kell, and Lutheran Blood Groups in the Human Population of Bosnia and Herzegovina

Lejla Lasic, ${ }^{1 *}$ Abdurahim Kalajdzic, ${ }^{1}$ Belma Kalamujic Stroil, ${ }^{1}$ Lejla Pojskic, ${ }^{1}$ Jasna Hanjalic, ${ }^{1}$ Lejla Usanovic, ${ }^{1}$ and Naris Pojskic ${ }^{1}$

${ }^{1}$ University of Sarajevo, Institute for Genetic Engineering and Biotechnology, Sarajevo, Bosnia and Herzegovina.

*Correspondence to: Lejla Lasic, University of Sarajevo, Institute for Genetic Engineering and Biotechnology, Zmaja od Bosne 8 (Kampus), Sarajevo 71000, Bosnia and Herzegovina. E-mail: lejla.lasic@ingeb.unsa.ba.

Short Title: Blood Group Molecular Variation in B\&H Population KEY WORDS: HUMAN POPULATIONS, POPULATION GENETICS, GENETIC DIVERSITY, BLOOD GROUP SYSTEMS. 


\section{Abstract}

Six blood groups (Rh, MN, Duffy, Kidd, Kell and Lutheran) were investigated among three major ethnic groups (Bosniaks, Bosnian Croats, and Bosnian Serbs) as well as ten regional subpopulations across Bosnia and Herzegovina (Krajina, Posavina, North-Eastern Bosnia, Eastern Bosnia, Middle Bosnia, Central Bosnia, Sarajevo Region, Eastern Herzegovina, Central Herzegovina, and Western Herzegovina). This is the first study that introduces the molecular genetic typing of five blood groups within the population of Bosnia and Herzegovina with the exception of $R h D$ blood group. The sample consisted of 450 buccal swabs from unrelated individuals. Five blood group systems ( $R h D, R h C, R h E, K i d d, M N)$ were genotyped by the PCR-SSP method, while three blood group systems (Kell, Duffy, Lutheran) were genotyped by the PCR-RFLP method. Minor variation of genetic diversity was observed within the three major ethnic groups in $\mathrm{B} \& \mathrm{H}$ as well as within the ten subpopulations stratified according to geographical criteria. No genetic differentiation among ethnic groups was noticed. These results are in agreement with the results of previous studies based on different molecular genetics markers, which indicate that the three ethnic groups of Bosnia and Herzegovina belong to the same gene pool. A similar level of genetic variance was observed within regional subpopulations with no significant genetic differentiation among them. Comparison of intrapopulation genetic diversity of the Bosnian and Herzegovinian population with other European and non-European populations, based on the three loci $(R H D, M N$ and $K E L)$, clearly showed that the level of genetic diversity of the Bosnia and Herzegovina population is within the European range. 
From a demographic and genetic perspective, Bosnia and Herzegovina $(\mathrm{B} \& \mathrm{H})$ is interwoven with several more or less isolated local populations of indigenous people and presents a very interesting area for population-genetic studies of different levels and orientations. B\&H is inhabited by three major ethnic subpopulations (Bosniaks, Bosnian Serbs and Bosnian Croats, more than $96 \%$ of the population) and 17 national minorities (http://www.popis2013.ba/). All three groups are Slavic. One generally recognized ethnic difference among the three groups is religion (Bosniaks are predominantly Muslims, Croats are mostly Catholic and Serbs are largely Orthodox Christian). Besides that, Bosnian, Croatian and Serbian are recognized as different official languages, but they are mutually intelligible. The history of population studies in B\&H dates back to the late 19th century (Himmel 1887; Weisbach 1895) and, according to the type of markers that were observed, can be separated into two main periods. Studies based on phenotypic markers conducted by different B\&H scientists in the 1970s and 1980s (Kaunic \& Grin 1963; Bošković 1975; Hadžiselimović 1977; 1981; Hadžiselimović \& Terzić 1985; Berberović 1969; 1976; 1978) provided the first reliable and medically relevant data about the distribution of $A B O, R h$ and $M N$ blood groups in $\mathrm{B} \& \mathrm{H}$. The distribution of phenotypic, biochemical and molecular genetic markers was investigated in geographically and ethnically defined subpopulations (Hadžiselimović 1981; Marjanović et al. 2004; 2005; 2006; Pojskić et al. 2005; Pojskić et al. 2010; Kovačević et al. 2014; Doğan et al. 2016; Ahmić et al. 2019). The results showed no statistically significant genetic differentiation among the three main ethnic groups or subpopulations from different geographical regions of $\mathrm{B} \& \mathrm{H}$, regardless of the markers used.

A blood type (also called a blood group) is a classification of blood, based on the presence or absence of inherited antigenic substances on the surface of red blood cells (RBCs) and the surface of other cell types of different tissues (Avent 1998). According to the International Society of Blood Transfusion (ISBT), about 33 blood groups and over 300 
different blood-group antigens have been found (Lögdberg et al. 2010), but many of these are very rare or mainly found in certain populations. Until molecular genetic analysis was introduced to the methodology in the late 20th century, the common way of detecting a particular blood group was based on serological analysis. The accordance between results based on serological and molecular-genetics methods for $R h D$ blood group was estimated in a comparative study performed by Lasić et al. (2013). Inter-rater agreement statistic (K, Kappa) was used with a $95 \%$ confidence interval. The results showed perfect agreement $(K=1)$ between the $R h D$ blood group detection based on serological and molecular-genetics methods. Study by Male et al. (2002) showed 100\% concordance between M/N antigen serotyping and the results obtained by PCR. An agreement of $100 \%$ between genotype and phenotype for Rh, Kell, Kidd and Duffy blood groups was noticed in blood donors control group (Castilho et al. 2000). The above-mentioned studies further corroborate our assumption that serological and molecular typing of analyzed blood groups also conform. Since blood groups are qualitative traits controlled by only one or a small number of genetic loci, it is relatively easy to do allele genotyping and calculate their frequency in respective populations. Therefore, the analysis of variation in blood groups is a convenient way to identify the genetic population structure (Bodmer 2015). This study introduces the molecular genetic typing of six blood groups (Rh, MN, Duffy, Kidd, Kell and Lutheran) and provides the first information about the genotypic and allelic frequencies of the Duffy, Kidd, Kell and Lutheran blood groups within the population of $\mathrm{B} \& \mathrm{H}$. In that sense, it complements the previously published data on the distribution phenotypes of the $A B O, R h$ and $M N$ blood group systems and contributes to the knowledge about the genetic structure of human populations that inhabit this area.

\section{Material and Methods}


A total of 450 unrelated individuals $(0.01 \%$ of total $\mathrm{B} \& \mathrm{H}$ population

(http://www.popis2013.ba/) from B\&H belonging to three major ethnic groups (Bosniaks, Bosnian Croats and Bosnian Serbs) as well as ten subpopulations (Figure 1) were observed. The subdivision of the $\mathrm{B} \& \mathrm{H}$ population into 10 different subpopulations was based on physical geographic and historic criteria. This geographic distribution was proposed by Pojskić et al. 2013. The sample comprised 240 Bosniaks, 116 Bosnian Croats and 94 Bosnian Serbs.

The regional sample size is shown in Table 1. Before sampling each participant was selected based on a questionnaire that provided data on personal, parental and grand-parental ethnic and geographic origin. Families of selected participants had lived at their present locations for over three generations. Samples were collected voluntarily from individuals after signing informed consent and being appropriately informed about the aim of the research. Six blood group systems (Rh, Kell, Kidd, Duffy, Lutheran and $M N$ ) were observed through eight loci (RHD, RHC, RHE, KEL, JK, $M N, F Y$ and $L U)$. Although $R H C$ and $R H E$ are related, they were treated as two independent loci. DNA was isolated from buccal swabs using the standard salting-out method (Miller et al. 1988). A qualitative-quantitative analysis of extracted DNA was done by spectrophotometry and agarose gel electrophoresis. Five blood group loci (RHD, RHE, RHC, $M N$ and $J K)$ were genotyped using the PCR-SSP method with protocols and primers previously described by other authors (Simsek et al. 1995; Faas et al. 1995; Avent 1998; Nakayashiki \& Sasaki 1996; Irshaid et al. 1998, respectively). The other three blood group loci $(K E L, F Y, L U)$ were genotyped by the PCR-RFLP method. For $K E L$ and $F Y$ we used protocols and primers described by Rios et al. (1999) and for the $L U$ locus protocols and primers by El Nemer et al. (1998). PCR products were separated on 2-3\% agarose gels and visualized with ethidium bromide. Gel analysis was carried out using the EDAS software (Kodak Electrophoresis Documentation and Analysis System). The 
mutations associated with each serologically defined phenotype whose MAF is listed in tables 1 and 2 are given in Supplementary Table 1.

The measures of heterogeneity for the analyzed populations were estimated by calculating allele and genotype frequencies as well as gene diversity (Nei 1987) and the inbreeding coefficient for individual subpopulations and overall. To estimate deviation from Hardy-Weinberg equilibrium, the exact p-value test (Guo \& Thompson 1992) was used. After Bonferroni correction, statistical significance for Hardy-Weinberg equilibrium departure test was considered as $p<0.001$. The above-mentioned parameters were calculated using POWERMARKER v3.25 (Liu \& Muse 2005).

For calculating genetic differentiation as well as genetic distance we used DISPAN (Ota 1993). It is important to point out that GsT, as a measure of genetic differentiation, for biallelic loci becomes identical to FST which is defined as $\sigma_{x}^{2} /\{\bar{X}(1-\bar{X})\}$ (Nei 1987). Gst as a parameter, estimates the proportion of genetic variation due to among-population genetic differentiation. Genetic distance $\left(\mathrm{D}_{\mathrm{A}}\right)$ was estimated using the method described by Nei et al. (1983). A Neighbor-Joining (NJ) dendrogram (Saitou \& Nei 1987) was constructed based on the results of genetic distance analysis assessing the relationship among the ten observed B\&H subpopulations. NJ dendrogram was created using MEGA 7 (Tamura et al. 2007). The deviation of average genetic distances between each subpopulation and all others from the average genetic distances among all subpopulations was calculated according to Hadžiselimović (1981) as ( $\square$ Ak $-\square$ At $) / \square$ At, or the index of genetic specificity (IGSP) where $\square \mathrm{Ak}$ is the value for the population average genetic distance and $\square_{\mathrm{At}}$ is the total average among all genetic distance values. The value of IGSP for each subpopulation shows the intensity and direction of deviation from the overall distance value. In this case a $p$-value was calculated as a statistical significance of this deviation. It is important to point out that a $\mathrm{z}-$ score of $p<0.05$ was considered statistically significant. The value of IGSP was calculated 
using IGSP script posted on INGEB's website (IGSP R script. Retrieved January 23, 2020, from http://ingeb.unsa.ba/popgen/R/igsp/igsp.html)

An analysis of molecular variance (AMOVA) (Excoffier et al. 1992) was used for the partitioning of genetic variation among the observed 10 subpopulations defined by geographic regions. The above-mentioned test was performed in POWERMARKER v3.25 (Liu \& Muse 2005).

We performed a non-metric multidimensional scaling (NM-MDS) (James \& Culloch 1990) in order to analyze the homogeneity of the genetic structure of each of the subpopulations defined according to ethnicity. We also used NM-MDS based on Euclidean distances for $R h D, M N$ and Kell blood type data to compare the B\&H population with 10 other European and three non-European populations. This analysis was performed in PAST v3.26 (Hammer et al. 2001). Comparison data for these three blood groups ( $R h D, M N$ and Kell) is presented in Supplementary Table 2. In order to estimate a $p$-value for differences between estimated gene diversities and allele frequencies, we used one-sample permutation tests within R programming language packages DAAG (number of permutations $=2000)(\mathrm{R}$ Core Team 2017). We used the permutation test in the PERM package within $\mathrm{R}$ programming language (R Core Team 2017) to assess the statistical significance of genetic differentiation at the 0.05 level of probability.

\section{Results and Discussion}

A comparison of ten regional subpopulations showed a significant deviation from HardyWeinberg equilibrium $(p<0.05)$ in seven of them. After Bonferroni correction, the level of statistical significance was changed to $p<0.001$, and only one subpopulation was in HardyWeinberg disequilibrium: Krajina for locus $F Y$. The highest average value of gene diversity was found in the subpopulation Krajina (0.392) and lowest in Central Herzegovina (0.328) 
(Table 1). A moderately high level of gene diversity within $L U$ locus $(0.219)$ could be attributed to the fact that great variation between central and south parts of our country exists. An overall intrapopulation inbreeding coefficient for all loci indicates that none of the studied subpopulations show a tendency for inbreeding. The average values of gene diversity within the three major ethnic groups of $\mathrm{B} \& \mathrm{H}$ were similar, ranging from 0.361 for Bosnian Croats to 0.376 for Bosnian Serbs, while the value of gene diversity for Bosniaks was 0.367 (Table 2). Observed differences of gene diversity within the three ethnic groups of $\mathrm{B} \& \mathrm{H}$ are minimal and do not significantly impact the genetic differences among ethnic groups. We have compared allele frequencies of the $M N$ and $R h$ blood groups in the population of $\mathrm{B} \& \mathrm{H}$ obtained by the molecular-genetic method from this study with allele frequencies obtained by the serological method in two studies (Berberović et al. 1976; Hadžiselimović \& Terzić, 1985; respectively). The allele frequencies obtained by Berberović et al. (1976) were, 0.537 for M allele and 0.463 for $\mathrm{N}$ allele, while Hadžiselimović \& Terzić (1985) reported 0.591 for the $R h D$ allele and 0.409 for the $R h d$ allele. The results obtained in this study, using molecular genetic methods, correspond to allele frequencies obtained by serological methods in the population of B\&H. No statistically significant difference was noticed between allele frequencies of $R h D$ and $M N$ loci when Berberović et al. (1976); Hadžiselimović \& Terzić (1985) and this study are compared ( $p$-value $=0.120)$. In the study by Pojskić et al. (2013), when other biallelic markers (Alu polymorphisms) were used, gene diversity ranged from 0.305 to 0.328 , showing that the average gene diversity of $\mathrm{B} \& \mathrm{H}$ population is lower than those found in a study that observed 18 Alu loci in European Mediterranean populations (Greek 0.363, North Spain 0.366, Central Spain 0.356, South Spain 0.358, South France 0.351) (González-Pérez et al. 2010). In the present survey, the mean values of the same parameter for the blood group markers spanned from 0.328 to 0.392 (Table 1). No statistically significant difference was noticed between values of gene diversity when the 
above-mentioned studies are in question $(p$-value $=0.252)$. Taking into account that this study included the same individuals as in Pojskić et al. (2013), it can be concluded that the genetic diversity of $\mathrm{B} \& \mathrm{H}$ population is higher when observed based on polymorphism of blood groups than on the Alu markers.

Analysis of molecular variance (AMOVA) of blood group loci detected moderate differentiation between the observed subpopulations defined by geographic regions. The lowest intrapopulation variation was observed in the Posavina subpopulation (0.0407), and the highest in the Sarajevo subpopulation (0.0656). Interpopulation variation was 0.0228 (2.28\%) which was consistent with the results of the genetic differentiation test. The overall genetic differentiation in ten regional subpopulations, stratified by geographic criteria, was $0.024(2.44 \%)$ (Table 1) which is greater than the value (0.009) detected in Pojskić et al. (2013) based on Alu polymorphism. No statistically significant difference was noticed between values of genetic differentiation in regional subpopulations from this and Pojskić et al. $(2013)$ study $(Z=1.836 ; p$-value $=0.06636)$. When three main ethnic groups in $\mathrm{B} \& \mathrm{H}$ are observed, a larger overall genetic differentiation (GST) was noticed in this study $(0.008-$ $0.8 \%$ ) (Table 2) than in one regarding Alu polymorphisms (0.003). The reason why values of genetic differentiation from this study are much higher than those observed in study about Alu polymorphisms (Pojskić et al. 2013) could be attributed to the fact that different markers were used in these studies. Tills (1977) studied different blood groups which included $A B O$, secretor, Lewis, MNSs, Rh, Kell, Duffy, Lutheran, Kidd, $P$ and Diego in world and European populations. Nonetheless, the value for blood group genetic differentiation in B\&H population is much lower than the one found for world populations (0.205; Tills 1977). However in comparison with European populations (Tills 1977), the value was close to identical (0.007). No statistically significant difference was noticed between values of genetic 
differentiation when we compared results from this study, Pojskić et al. (2013) and Tills (1977) study $(\mathrm{Z}=1.683 ; p$-value $=0.09135)$.

The values of genetic distance among regional subpopulations do not digress significantly, suggesting that these subpopulations are very close in the context of the distribution of the six analyzed blood groups. The highest value of genetic distance was detected among the subpopulations of Eastern Herzegovina and Central Herzegovina (0.0163) while the lowest value was among the subpopulations of North-Eastern Bosnia and Western Herzegovina (0.0010) (Table 3). These genetic distances are consistent with the neighbor-joining dendrogram; however, they are not consistent with geographic proximity of the studied subpopulations. The index of genetic specificity (IGSP) showed no statistically significant deviation of the average genetic distance of each subpopulation from the overall distance (Table 4). These results indicate that the genetic distances among the subpopulations are without major variation. This finding further supports the conclusion that there is no major genetic differentiation of observed markers within B\&H taking into consideration geographical parameters without ethnic affiliation of the subjects. The neighbor-joining dendrogram showed two major groups of clusters (Figure 2). The first one includes Eastern Herzegovina and Middle Bosnia together with Central Bosnia, Krajina and Eastern Bosnia. The other one includes North-Eastern Bosnia, Western Herzegovina, Sarajevo region, Central Herzegovina and Posavina. These findings are based on the results of genetic distance among 10 observed subpopulations stratified upon geographic criteria. Since the observed genetic distances between these subpopulations were very small (Table 3), we can conclude that the topology of the subpopulations within the NJ dendrogram may not reflect any solid genetic difference based on observed markers or do not follow the geographical distribution of regions (Figures 1 and 2). For the purpose of obtaining information regarding the homogeneity of the genetic structure of each subpopulation defined by ethnic affiliation, we 
conducted non-metric multidimensional scaling (NM-MDS). This graph, created on the basis of frequencies of eight loci from six blood group systems, showed the dispersion of samples and a lack of differentiation of samples according to their ethnicity (Figure 3). Non-metric multidimensional scaling (NM-MDS) analysis of 10 European and three non-European populations (Figure 4) based on data from three blood group systems ( $R h D, M N, \mathrm{Kell})$, showed a clear clustering of European populations. Also, this analysis positioned B\&H much closer to European populations than to non-European populations (India, China and South Korea). B\&H was positioned nearest to Germany, Norway, Denmark and United Kingdom. A slightly greater distance was noticed between our population on one side and Serbia, Sweden, Ireland and France populations on the other side. Our population, in regards to European populations, positioned the farthest from Spain and Iceland populations. In context of other non-European populations, the largest distance was noticed between South Korea and China on one side, and on the other, a cluster of European populations. A slightly smaller distance was observed between European populations and India. These results are quite in concordance with results of previous studies based on STRs (Marjanovic et al. 2004; 2006), Y STRs (Marjanovic et al. 2006; Doğan et al. 2016), mtDNA haplogroups and CYTB (Kapur et al. 2003; Pojskić 2005, Kovačević et al. 2014, Ahmić et al. 2019). All the above-mentioned studies that were performed on the B\&H population indicate no statistically significant genetic differentiation among analysed subpopulations regardless of the geographical and ethnic structure. The only exception with statistically significant genetic differentiation among three ethnic groups was found in the study of Marjanovic et al. (2005). They found that Bosnian Croats were the most homogeneous group $(\mathrm{H}=0,470)$ where the frequency of observed sub-haplogroup I-P37 was particularly high (71.1\%). These results are explained by the influence of genetic drift, given that the samples of Bosnian Croats, by demographic parameters, are from a limited part of B\&H (mostly from Western Herzegovina), and 
especially by the fact that the number of Croats in $\mathrm{B} \& \mathrm{H}$ is relatively small, with the emphasis on extensive emigration. Such results were confirmed by the study of Doğan et al. (2016). Overall, we can conclude that the B\&H population, regardless of the geographical and ethnic structure, has quite close relations with European populations and shows a clear European genetic background.

\section{Conclusion}

This study provided the first data on polymorphisms of $R h C, R h E, K e l l$, Duffy, Kidd, and Lutheran blood groups in the population of $\mathrm{B} \& \mathrm{H}$ and their variation with regards to regional or ethnic affiliation. Also, this research has contributed to completing the picture of the genetic structure of subpopulations and inhabitants, complementing the results of previous investigations of other molecular genetic markers such as nuclear STR, mitochondrial HV regions, Y-chromosome markers, and Alu polymorphisms. It can be concluded that there is no significant differentiation among geographically or ethnically defined subpopulations in $\mathrm{B} \& \mathrm{H}$. These results are in agreement with the results of previous studies, indicating that $\mathrm{B} \& \mathrm{H}$ represents a unique region and that three major ethnic groups in the country belong to the same gene pool, sharing the same origin as a part of European genetic background.

Received 19 February 2020; accepted for publication 28 August 2020. 


\section{Literature Cited}

Agency for Statistics of Bosnia and Herzegovina. 2016. Census of Population, Households and Dwellings in Bosnia and Herzegovina, 2013: Final Results. Sarajevo, BA: Agency for Statistics of Bosnia and Herzegovina.

Ahmić, A., I. Mujkić, A. Ismailović et al. 2019. Analysis of the mitochondrial CYTB gene sequence in human populations of North-Eastern Bosnia. Anthropol. Rev. 82:219238.

Avent, N. D. 1998. Antenatal genotyping of the blood groups of the fetus. Vox Sang. 74:365374.

Basu, D., S. S. Datta, C. Montemayor et al. 2018. ABO, Rhesus and Kell antigens, alleles and haplotypes in West Bengal, India. Transfus. Med. Hemother. 45:62-66.

Berberović, L. J. 1969. Theoretical frequencies of allelogenes IA, IB and $\mathrm{I}^{\circ}$ in the population of Bosnia and Hercegovina. Acta Medica Iugoslavica 23:62.

Berberović, L. J. 1978. Populaciono-genetička analiza učestalosti alternativnih fenotipova sekrecije ABH antigena u dvanaest uzoraka stanovništva BiH. Glas. Antropol. Druš. Jugosl. 5:47-59.

Berberović, L. J., R. Hadžiselimović, C. Marić et al. 1976. Populacijska genetika osnovnih krvnih grupa MN sistema u uzorku slučajeva spornog očinstva. I. Kongres Genet. Jugosl. Sažeci:14.

Bodmer, W. 2015. Genetic characterization of human populations: From ABO to a genetic map of the British people. Genetics 199:267-279.

Bošković, S. 1975. Transfuziologija. Sarajevo, BA: Svjetlost.

Campillo, F. L., L. E. Gallardo, and A. Senra. 1973. Distribution of the Kell blood groups in the Spanish population. Hum. Hered. 23:499-500. 
Castilho, L., M. Rios, J. Pellegrino Jr. et al. 2000. Genotyping of Kell, Duffy, Kidd and RHD in patients with $\beta$ Thalassemia. Rev. Bras. Hematol. Hemoter. 22:69-76.

Chakraborty, S. 2010. Gene frequency and heritability of Rh blood group gene in 44 human populations. Not. Sci. Biol. 2:16-19.

Daniels, G. 2005. The molecular genetics of blood group polymorphism. Transpl. Immunol. $14: 143-153$.

Doğan, S., A. Ašić, G. Doğan et al. 2016. Y-chromosome haplogroups in the BosnianHerzegovinian population based on 23 Y-STR loci. Hum. Biol. 88:201-209.

El Nemer, W., P. Gane, Y. Colin et al. 1998. The Lutheran blood group glycoproteins, the erythroid receptors for laminin, are adhesion molecules. J. Biol. Chem. 273:16,686$16,693$.

Excoffier, L., P. Smouse, and J. Quatro. 1992. Analysis of molecular variance inferred from metric distances among DNA haplotypes: Application to human mitochondrial DNA restriction data. Genetics 131:479-491.

Faas, B. H. W., S. Simsek, P. M. M. Bleeker et al. 1995. Rh E/e genotyping by allele-specific primer amplification. Blood 3:829-832.

González-Pérez, E., E. Esteban, M. Marc Via et al. 2010. Population relationships in the Mediterranean revealed by autosomal genetic data (Alu and Alu/STR compound systems). Am. J. Phys. Anthropol. 141:430-439.

Guo, S. W., and E. A. Thompson. 1992. Performing the exact test of Hardy-Weinberg proportion for multiple alleles. Biometrics 48:361-372.

Hadžiselimović, R. 1977. Genetika sekrecije ABH antigena u stanovništvu Bosne i Hercegovine. God. Biol. Instituta Univ. Sarajevu. 30:29-104.

Hadžiselimović, R. 1981. Genetic distance among local human population in Bosnia and Herzegovina (Yugoslavia). Coll. Antropol. 5:63. 
Hadžiselimović, R., and R. Terzić. 1985. Populacijska genetika krvnih grupa ABO i Rh sistema u stanovništvu banjalučke i bihaćke regije. God. Biol. Instituta Univ. Sarajevu. 38:143-150.

Hammer, Ø., D. A. T. Harper, and P. D. Ryan. 2001. PAST: Paleontological Statistics Software Package for education and data analysis. Palaeontol. Electronica 4:9.

Heiken, A. 1962. Distribution of the Kell blood group factor K in the Swedish population. Acta Genet. Stat. Med. 12:352-358.

Heiken, A. 1965. A genetic study of the MNSs blood group system. Hereditas 53:187-211.

Himmel, H. 1887. Mittelungen der Anthropologischen Gesellschaft in Wien. 17-84.

IGSP SCRIPT. Index of Genetic Specificity (IGSP). Sarajevo, BA: Institute of Genetic Engineering and Biotechnology, University of Sarajevo. http://ingeb.unsa.ba/popgen/R/igsp/igsp.html (accessed 23 January 2020).

Irshaid, N. M., B. Thuresson, and M. L. Olsson. 1998. Genomic typing of the Kidd blood group locus by a single-tube allele-specific primer PCR technique. Br. J. Haematol. $102: 1,010-1,014$.

James, F., and C. M. Culloch. 1990. Multivariate analysis in ecology and systematics: Panacea or pandora box? Annu. Rev. Ecol. Evol. Syst. 21:129-199.

Kapur, L., N. Pojskic, D. Marjanovic et al. 2003. mtDNA diversity in local human populations after war resettlement. In DNA Polymorphisms in Human Populations, 2nd International Symposium, December 2003, Paris, France. http://ecoanthropologie.mnhn.fr/abstracts\%20coi\%20link.html.

Kaunić, P., and E. Grin. 1963. Naučno društvo BiH - Posebna izdanja. 3-621.

Kherumian, R., J. Moullec, and N. Van Cong. 1967. Groupes sanguins érythrocytaires A1, A2, BO, MN, $\mathrm{Rh}(\mathrm{CcDE})$ et sériques, $\mathrm{Hp}, \mathrm{Tf}, \mathrm{Gm}$ dans quatre régions militaires françaises. Bull. Mém. Soc. Anthropol. Paris 4:377-384. 
Kovacevic, L., K. Tambets, A. M. Ilumäe et al. 2014. Standing at the gateway to Europe: The genetic structure of Western Balkan populations based on autosomal and haploid markers. PLoS One 9:e105090.

Lasić, L., N. Lojo-Kadrić, E. Silajdžić et al. 2013. Molecular - genetic variance of RH blood group system within human population of Bosnia and Herzegovina. Bosn. J. Basic Med. Sci. 13:10-13.

Liu, K., and S. V. Muse. 2005. PowerMarker: Integrated analysis environment for genetic marker data. Bioinformatics 21:2,128-2,129.

Lögdberg, L., M. E. Reid, and T. Zelinski. 2011. Human blood group genes 2010: Chromosomal locations and cloning strategies revisited. Transfus. Med. Rev. 25:3646.

Male, D. A., P. Phillips, and D. R. Turner. 2002. Improved polymerase chain reaction-based glycophorin-A M/N blood group allelotyping. Vox Sang. 83:170-171.

Marjanović, D., N. Bakal, N. Pojskić et al. 2006. Allele frequencies for 15 short tandem repeat loci in a representative sample of Bosnians and Herzegovinians. Forensic Sci. Int. 156:79-81.

Marjanović, D., S. Fornarino, S. Montagna et al. 2005. The peopling of modern BosniaHerzegovina: Y-chromosome haplogroups in the three main ethnic groups. Ann. Hum. Genet. 69:757-763.

Marjanović, D., L. Kapur, K. Drobnić et al. 2004. Comparative study of genetic variation at 15 STR loci in three isolated populations of the Bosnian mountain area. Hum. Biol. 76:15-31.

Miller, S. A., D. D. Dykes, and H. F. Polesky. 1988. A simple salting out procedure for extracting DNA from human nucleated cells. Nucleic Acids Res. 16:1215. 
Nakayashiki, N., and Y. Sasaki. 1996. An improved method for MN genotyping by the polymerase chain reaction. Int. J. Legal Med. 109:216-217.

Nei, M. 1987. Molecular Evolutionary Genetics. New York: Columbia University Press.

Nei, M., F. Tajima, and Y. Tateno. 1983. Accuracy of estimated phylogenetic trees from molecular data. J. Mol. Evol. 19:153-170.

Ota, T. 1993. DISPAN: Genetic Distance and Phylogenetic Analysis. University Park, PA: Institute of Molecular Evolutionary Genetics, The Pennsylvania State University.

Pojskić, N. 2005. mtDNA hypervariable regions in determination of local human populations diversity after war resettlement. Eur. J. Hum. Genet. 13:357.

Pojskić, N., D. Marjanović, E. Silajdžić et al. 2010. Concordance of different genetic markers in human population studies. Eur. J. Hum. Genet. 18:253.

Pojskic, N., E. Silajdzic, B. Kalamujic et al. 2013. Polymorphic Alu insertions in human populations of Bosnia and Herzegovina. Ann. Hum. Biol. 40:181-185.

Rajeevan, H., M. V. Osier, K.-H. Cheung et al. 2003. ALFRED: The ALelle FREquency Database. Update. Am. J. Phys. Anthropol. 31:270-271.

R Core Team. 2017. R: A Language and Environment for Statistical Computing. Vienna: R Foundation for Statistical Computing. http://www.R-project.org/.

Rios, M., K. Cash, A. Strupp et al. 1999. DNA from urine sediment or buccal cells can be used for blood group molecular genotyping. Immunohematology 15:61-65.

Saitou, N., and M. Nei. 1987. The neighbor-joining method: A new method for reconstructing phylogenetic trees. Mol. Biol. Evol. 4:406-425.

Simsek, S., B. H. Faas, P. M. Bleeker et al. 1995. Rapid RhD genotyping by polymerase chain reaction-based amplification of DNA. Blood 10:2,975-2,980.

Tamura, K., J. Dudley, M. Nei et al. 2007. MEGA4: Molecular Evolutionary Genetics Analysis (MEGA) software version 4.0. Mol. Biol. Evol. 24:1,596-1,599. 
Thakral, B., K. Saluja, R. R. Sharma et al. 2010. Phenotype frequencies of blood group systems (Rh, Kell, Kidd, Duffy, MNS, P, Lewis and Lutheran) in North Indian blood donors. Transfus. Apher. Sci. 43:17-22.

Tills, D. 1977. The use of the FST statistic of wright for estimating the effects of genetic drift, selection and migration in populations, with special reference to Ireland. Hum. Hered. 27:153-159.

Weisbach, A. 1895. Mittelungen der Anthropologischen Gesellschaft in Wien. 25-206.

Won, C. D., H. S. Shin, S. W. Kim et al. 1960. Distribution of hereditary blood factors among Koreans residing in Seoul, Korea. Am. J. Phys. Anthropol. 18:115-124.

Zhong, L., R. Zeng, C. Qing et al. 2012. Genotyping for Kidd, Kell, Duffy, Scianna and RHCE blood group antigens polymorphisms in Jiangsu Chinese Han. Chin. Med. J. 125:1,076-1,081. 
Table 1. Allele Frequencies, Gene Diversity and Gst Values for Eight Analyzed Loci in Ten Regional Subpopulations of Bosnia and Herzegovina

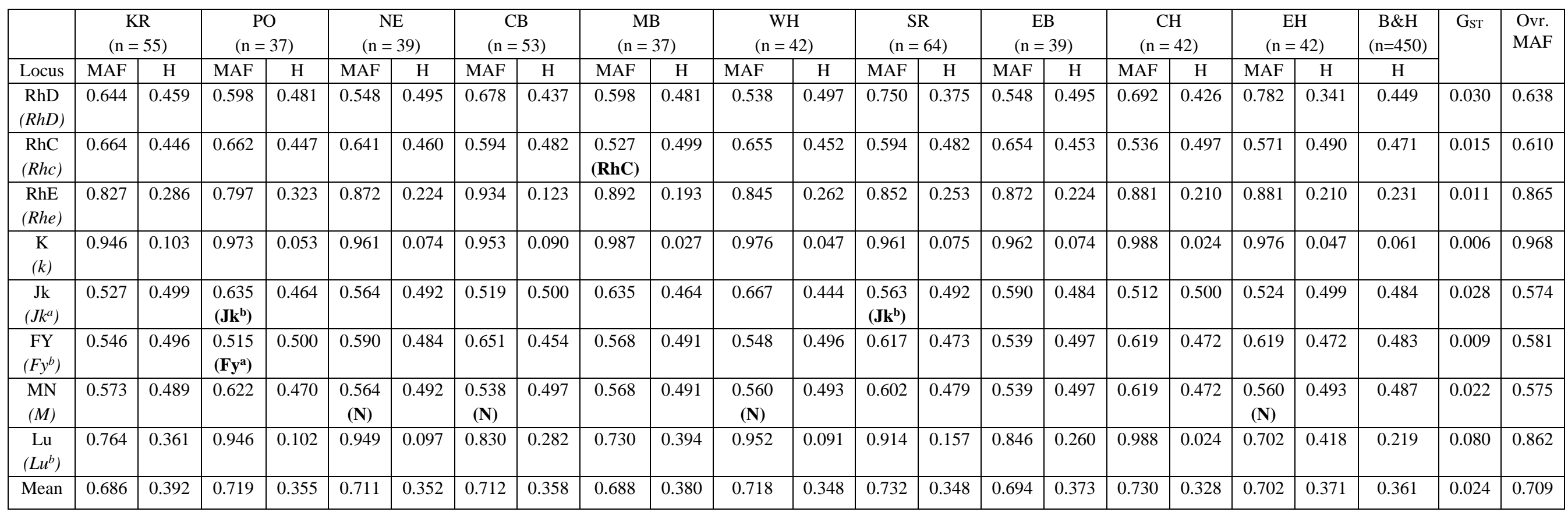

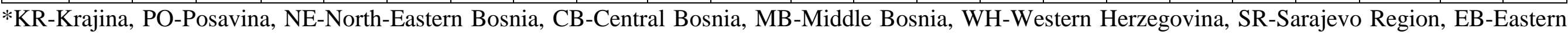

Bosnia, CH-Central Herzegovina, EH-Eastern Herzegovina; B\&H-Bosnia and Herzegovina; MAF= major allele frequency; Ovr. MAF=overall MAF for B\&H

(unweighted estimates); $\quad \mathrm{H}=$ gene diversity; GsT = locus GsT (GsT - measure of genetic differentiation); in column Locus in each bracket is given the identity of the allele whose frequency is being cited for majority of subpopulations except for some subpopulations in which case we stated the allele identity in bold next to its MAF.

Pre-print version. Visit http://digitalcommons.wayne.edu/humbiol/ after publication to acquire the final version. 
Table 2. Allele Frequencies, Gene Diversity and Gst Values for Eight Analyzed Loci in Three Main Ethnic Groups of Bosnia and

\section{Herzegovina}

\begin{tabular}{|c|c|c|c|c|c|c|c|c|c|}
\hline & \multicolumn{2}{|c|}{$\begin{array}{l}\text { BOSNK } \\
(\mathrm{n}=240)\end{array}$} & \multicolumn{2}{|c|}{$\begin{array}{c}\text { BOSCR } \\
(\mathrm{n}=116)\end{array}$} & \multicolumn{2}{|c|}{$\begin{array}{l}\text { BOSSR } \\
(\mathrm{n}=94)\end{array}$} & \multicolumn{3}{|c|}{ Overall } \\
\hline Locus & MAF & $\mathrm{H}$ & MAF & $\mathrm{H}$ & MAF & $\mathrm{H}$ & $\mathrm{H}$ & $\mathrm{G}_{\mathrm{ST}}$ & $\mathrm{MAF}^{*}$ \\
\hline $\begin{array}{l}\mathrm{RhD} \\
(R h D)\end{array}$ & 0.684 & 0.432 & 0.545 & 0.496 & 0.643 & 0.459 & 0.462 & 0.014 & 0.624 \\
\hline $\begin{array}{l}\mathrm{RhC} \\
(R h c)\end{array}$ & 0.594 & 0.482 & 0.603 & 0.479 & 0.638 & 0.462 & 0.498 & 0.002 & 0.612 \\
\hline $\begin{array}{l}\text { RhE } \\
\text { (Rhe) }\end{array}$ & 0.856 & 0.246 & 0.853 & 0.250 & 0.904 & 0.173 & 0.223 & 0.005 & 0.871 \\
\hline $\begin{array}{c}\mathrm{K} \\
(k)\end{array}$ & 0.965 & 0.068 & 0.983 & 0.034 & 0.952 & 0.091 & 0.064 & 0.005 & 0.967 \\
\hline $\begin{array}{c}\mathrm{Jk} \\
\left(J k^{a}\right)\end{array}$ & 0.513 & 0.500 & 0.565 & 0.492 & 0.527 & 0.499 & 0.497 & 0.002 & 0.535 \\
\hline $\begin{array}{c}\mathrm{FY} \\
\left(F y^{b}\right)\end{array}$ & 0.624 & 0.469 & $\begin{array}{l}0.509 \\
\left(\mathbf{F y}^{\mathbf{a}}\right) \\
\end{array}$ & 0.500 & 0.590 & 0.484 & 0.484 & 0.013 & 0.574 \\
\hline $\begin{array}{l}\mathrm{MN} \\
(M) \\
\end{array}$ & 0.540 & 0.497 & 0.530 & 0.498 & 0.516 & 0.499 & 0.498 & 0.000 & 0.529 \\
\hline $\begin{array}{c}\mathrm{Lu} \\
\left(L u^{b}\right)\end{array}$ & 0.860 & 0.240 & 0.927 & 0.136 & 0.782 & 0.341 & 0.239 & 0.030 & 0.856 \\
\hline Mean & 0.705 & 0.367 & 0.689 & 0.361 & 0.694 & 0.376 & 0.368 & 0.008 & 0.696 \\
\hline
\end{tabular}

*BOSNK-Bosniaks, BOSCR-Bosnian Croats, BOSSR-Bosnian Serbs; MAF= major allele frequency; MAF*=overall MAF for three main ethnic groups in $\mathrm{B} \& \mathrm{H}$ (unweighted estimates); $\mathrm{H}=$ gene diversity; Gst = estimation of Gst (GsT - measure of genetic differentiation); in column Locus 
in each bracket is given the identity of the allele whose frequency is being cited for majority of ethnic groups except for BOSCR for $F Y$ locus in which case we stated the allele identity in bold next to its MAF. 
Table 3. Nei's $D_{A}$ Genetic Distance (1983) between Ten Analyzed Subpopulations

\begin{tabular}{|c|c|c|c|c|c|c|c|c|c|c|}
\hline Pop & $\mathrm{CB}$ & $\mathrm{CH}$ & EB & $\mathrm{EH}$ & $\mathrm{KR}$ & $\mathrm{PO}$ & $\mathrm{SA}$ & $\mathrm{MB}$ & $\mathrm{NE}$ & WH \\
\hline \multicolumn{11}{|l|}{$\overline{\mathrm{CB}}$} \\
\hline $\mathrm{CH}$ & 0.0093 & & & & & & & & & \\
\hline $\mathrm{EB}$ & 0.0036 & 0.0094 & & & & & & & & \\
\hline $\mathrm{EH}$ & 0.0032 & 0.0163 & 0.0077 & & & & & & & \\
\hline $\mathrm{KR}$ & 0.0041 & 0.0129 & 0.0019 & 0.0046 & & & & & & \\
\hline PO & 0.0107 & 0.0062 & 0.0065 & 0.0160 & 0.0072 & & & & & \\
\hline SA & 0.0043 & 0.0037 & 0.0059 & 0.0073 & 0.0050 & 0.0041 & & & & \\
\hline $\mathrm{MB}$ & 0.0053 & 0.0140 & 0.0043 & 0.0053 & 0.0048 & 0.0148 & 0.0098 & & & \\
\hline $\mathrm{NE}$ & 0.0048 & 0.0058 & 0.0028 & 0.0121 & 0.0072 & 0.0063 & 0.0061 & 0.0102 & & \\
\hline WH & 0.0079 & 0.0075 & 0.0033 & 0.0144 & 0.0087 & 0.0087 & 0.0092 & 0.0105 & 0.0010 & \\
\hline
\end{tabular}

*Pop-Populations, CB-Central Bosnia, CH-Central Herzegovina, EB-Eastern Bosnia, EH-Eastern Herzegovina, KR-Krajina, PO-Posavina, SASarajevo region, MB-Middle Bosnia, NE-North-Eastern Bosnia, WH-Western Herzegovina. 
Table 4. IGSP Values and Its $p$ Value for Observed Ten Subpopulations Based on the Results of Nei's D $D_{A}$ Genetic Distance (1983)

\begin{tabular}{ccc}
\hline Pop & IGSP (I) & $p$ (I) \\
\hline CB & -0.2012 & 0.5246 \\
CH & 0.2778 & 0.3797 \\
EB & -0.3183 & 0.3141 \\
EH & 0.3048 & 0.3351 \\
KR & -0.1532 & 0.6281 \\
PO & 0.2087 & 0.5093 \\
SA & -0.1682 & 0.5948 \\
MB & 0.1862 & 0.5560 \\
NE & -0.1547 & 0.6247 \\
WH & 0.0691 & 0.8270
\end{tabular}

*Pop-Populations, IGSP - Index of Genetic Specificity, p-value, CB-Central Bosnia, CH-Central Herzegovina, EB-Eastern Bosnia, EH-Eastern Herzegovina, KR-Krajina, PO-Posavina, SA-Sarajevo region, MB-Middle Bosnia, NE-North-Eastern Bosnia, WH-Western Herzegovina. 
Supplementary Table S1. The Mutations Associated with Each Serologically Defined Phenotype

\begin{tabular}{|c|c|c|c|c|c|}
\hline Locus & $\begin{array}{c}\text { Chromosome } \\
\text { location }\end{array}$ & $\begin{array}{c}\text { Nucleotide } \\
\text { change }\end{array}$ & Amino acid change & Specificity & Reference \\
\hline$R H D$ & $1 \mathrm{p} 36.11$ & $*$ & $*$ & $\mathrm{D}>\mathrm{d}$ & \multirow{8}{*}{ Daniels, 2005} \\
\hline RHCE & $1 \mathrm{p} 36.11$ & $\begin{array}{l}48 \mathrm{C}>\mathrm{G} \\
178 \mathrm{~A}>\mathrm{C} \\
203 \mathrm{G}>\mathrm{A} \\
307 \mathrm{~T}>\mathrm{C}\end{array}$ & $\begin{array}{l}\text { Cys16Trp, Ile60Leu, } \\
\text { Ser68Asn,Ser103Pro }\end{array}$ & $\mathrm{C}>\mathrm{c}$ & \\
\hline RHCE & $1 \mathrm{p} 36.11$ & $676 \mathrm{G}>\mathrm{C}$ & Ala226Pro & $E>e$ & \\
\hline$K E L$ & $7 q 34$ & $578 \mathrm{~T}>\mathrm{C}$ & Met193Thr & $\mathrm{K}>\mathrm{k}$ & \\
\hline$J K$ & $18 q 12.3$ & $838 \mathrm{G}>\mathrm{A}$ & Asp280Asn & $\mathrm{Jk}^{\mathrm{a}}>\mathrm{Jk}^{\mathrm{b}}$ & \\
\hline$F Y$ & $1 \mathrm{q} 23.2$ & $125 \mathrm{G}>\mathrm{A}$ & Gly42Asp & $\mathrm{Fy}^{\mathrm{a}}>\mathrm{Fy}^{\mathrm{b}}$ & \\
\hline$M N$ & $4 q 31.21$ & $\begin{array}{l}59 \mathrm{C}>\mathrm{T} \\
71 \mathrm{G}>\mathrm{A} \\
72 \mathrm{~T}>\mathrm{G}\end{array}$ & $\begin{array}{l}\text { Ser20Leu, } \\
\text { Gly24Glu }\end{array}$ & $\mathrm{M}>\mathrm{N}$ & \\
\hline$L U$ & $19 q 13.32$ & $230 A>G$ & His77Arg & $\mathrm{Lu}^{\mathrm{a}}>\mathrm{Lu}^{\mathrm{b}}$ & \\
\hline
\end{tabular}

*- Rhd phenotype is caused by the deletion of whole RHD gene in Caucasian population. 
Supplementary Table S2. Comparison Data for Three Blood Groups (RhD, MN and Kell)

\begin{tabular}{|c|c|c|c|c|c|c|c|}
\hline Population & $R h D$ & Rhd & $M$ & $N$ & $K$ & $\boldsymbol{k}$ & Reference \\
\hline Serbia & 0.650 & 0.350 & 0.580 & 0.420 & 0.030 & 0.970 & Kidd et al. 2003 \\
\hline Germany & 0.589 & 0.411 & 0.550 & 0.450 & 0.040 & 0.960 & Kidd et al. 2003 \\
\hline Denmark & 0.600 & 0.400 & 0.531 & 0.469 & 0.034 & 0.966 & Kidd et al. 2003 \\
\hline Iceland & 0.610 & 0.390 & 0.591 & 0.409 & 0.054 & 0.946 & Chakraborty 2010; Kidd et al. 2003 \\
\hline Norway & 0.620 & 0.380 & 0.548 & 0.452 & 0.045 & 0.955 & Chakraborty 2010; Kidd et al. 2003 \\
\hline Sweden & 0.600 & 0.400 & 0.563 & 0.437 & 0.036 & 0.964 & Heiken 1962; Heiken 1965; Kidd et al. 2003 \\
\hline Spain & 0.570 & 0.430 & 0.507 & 0.493 & 0.038 & 0.962 & $\begin{array}{l}\text { Campillo et al. 1973; Chakraborty 2010; Kidd et } \\
\text { al. } 2003\end{array}$ \\
\hline France & 0.610 & 0.390 & 0.567 & 0.433 & 0.044 & 0.956 & $\begin{array}{c}\text { Chakraborty 2010; Kherumian et al. 1967; Kidd } \\
\text { et al. } 2003\end{array}$ \\
\hline United Kingdom & 0.590 & 0.410 & 0.534 & 0.466 & 0.046 & 0.954 & Chakraborty 2010; Kidd et al. 2003 \\
\hline Ireland & 0.600 & 0.400 & 0.570 & 0.430 & 0.040 & 0.960 & Chakraborty 2010; Kidd et al. 2003 \\
\hline $\begin{array}{c}\text { Bosnia and } \\
\text { Herzegovina }\end{array}$ & 0.637 & 0.363 & 0.532 & 0.468 & 0.033 & 0.967 & This study \\
\hline India & 0.760 & 0.240 & 0.504 & 0.496 & 0.004 & 0.996 & $\begin{array}{l}\text { Basu et al. 2018; Chakraborty 2010; Thakral et } \\
\text { al. } 2010\end{array}$ \\
\hline South Korea & 0.950 & 0.050 & 0.486 & 0.514 & 0.000 & 1.000 & Chakraborty 2010; Won et al. 1960 \\
\hline China & 0.900 & 0.100 & 0.575 & 0.425 & 0.000 & 1.000 & $\begin{array}{l}\text { Chakraborty 2010; Won et al. 1960; Zhong et al. } \\
\qquad 2012\end{array}$ \\
\hline
\end{tabular}




\section{Figure Captions}

Figure 1. Map of regions observed in this study; 1 - Krajina (KR); 2 - Posavina (PO); 3 North-Eastern Bosnia (NE); 4 - Central Bosnia (CB); 5 - Middle Bosnia (MB); 6 - Western Herzegovina (WH); 7 - Sarajevo Region (SR); 8 - Eastern Bosnia (EB), 9 - Central Herzegovina $(\mathrm{CH}) ; 10$ - Eastern Herzegovina (EH)

Figure 2. Neighbor-Joining dendrogram for ten analyzed subpopulations (in brackets next to each subpopulation name is given ID number from Figure 1)

Figure 3. NM-MDS diagram of 450 samples grouped according to ethnicity $(\bullet-$ Bosniaks, $\square$ - Bosnian Croats, + - Bosnian Serbs)

Figure 4. NM-MDS diagram of 14 analyzed populations based on $R h D, M N$ and $K e l l$ blood type data; Abbreviations: UK- United Kingdom; SK - South Korea; B\&H - Bosnia and Herzegovina 
Figure 1.

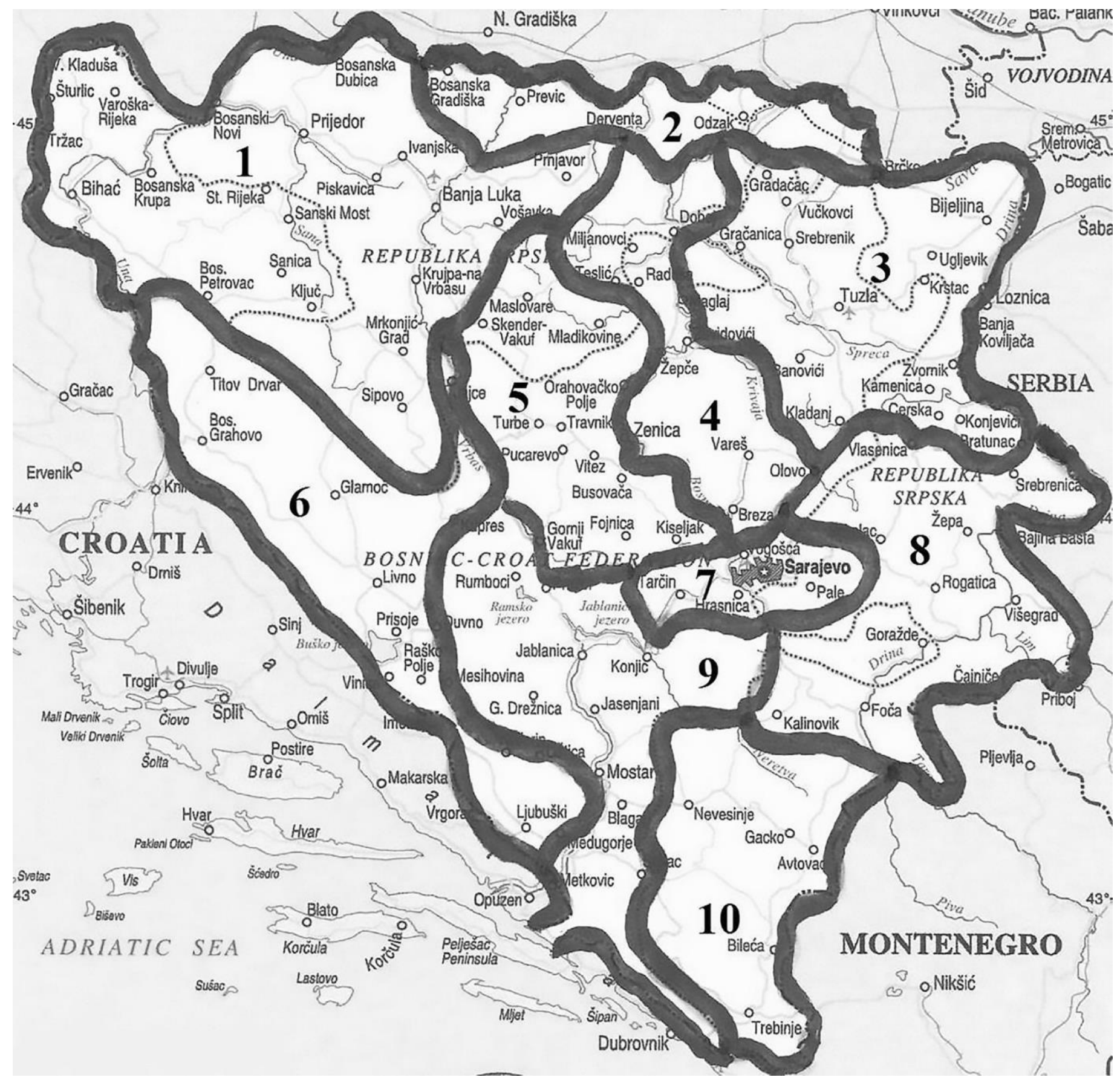

Pre-print version. Visit http://digitalcommons.wayne.edu/humbiol/ after publication to acquire the final version. 
Figure 2.

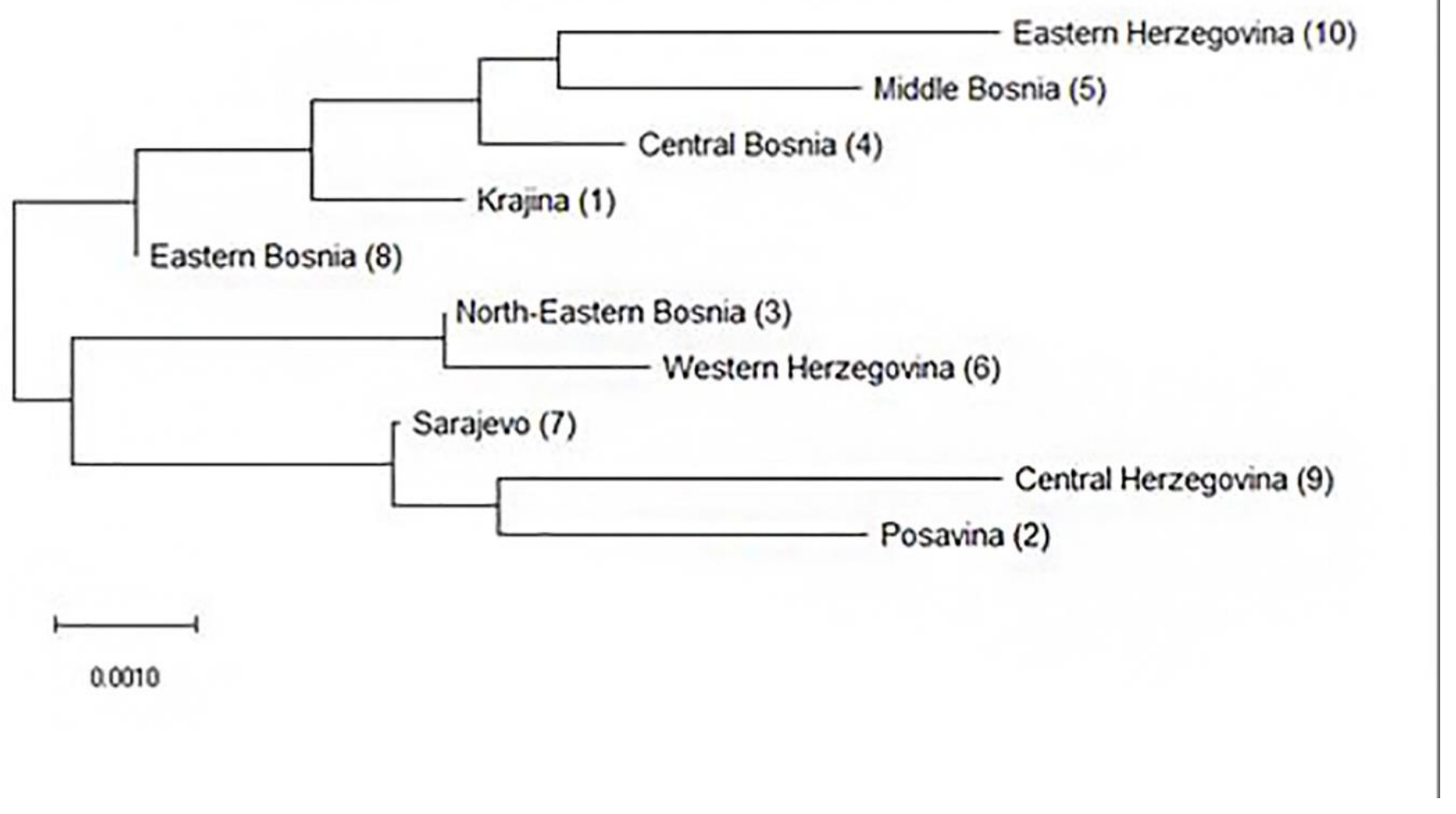

Pre-print version. Visit http://digitalcommons.wayne.edu/humbiol/ after publication to acquire the final version. 
Figure 3.

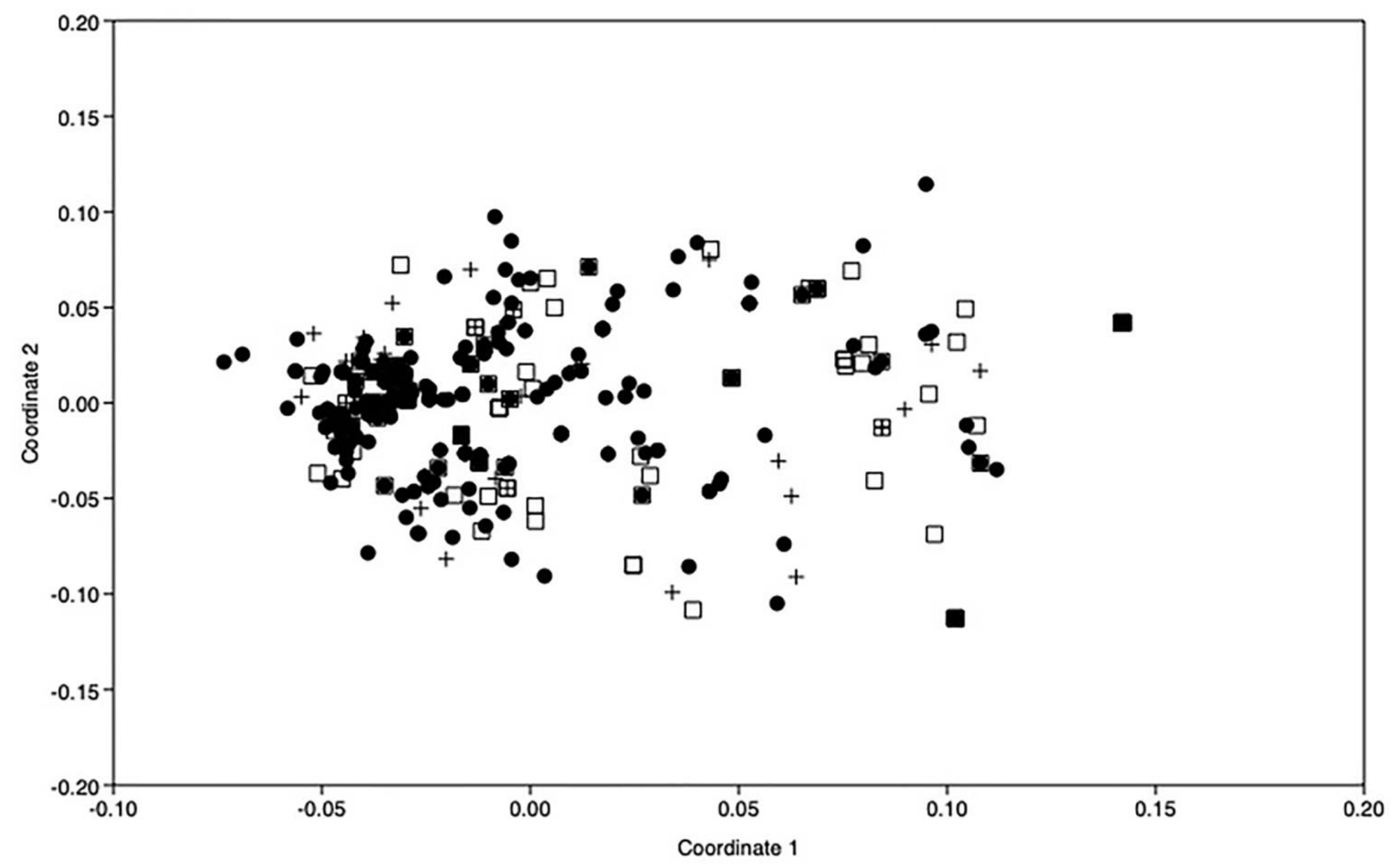

Pre-print version. Visit http://digitalcommons.wayne.edu/humbiol/ after publication to acquire the final version. 
Figure 4.

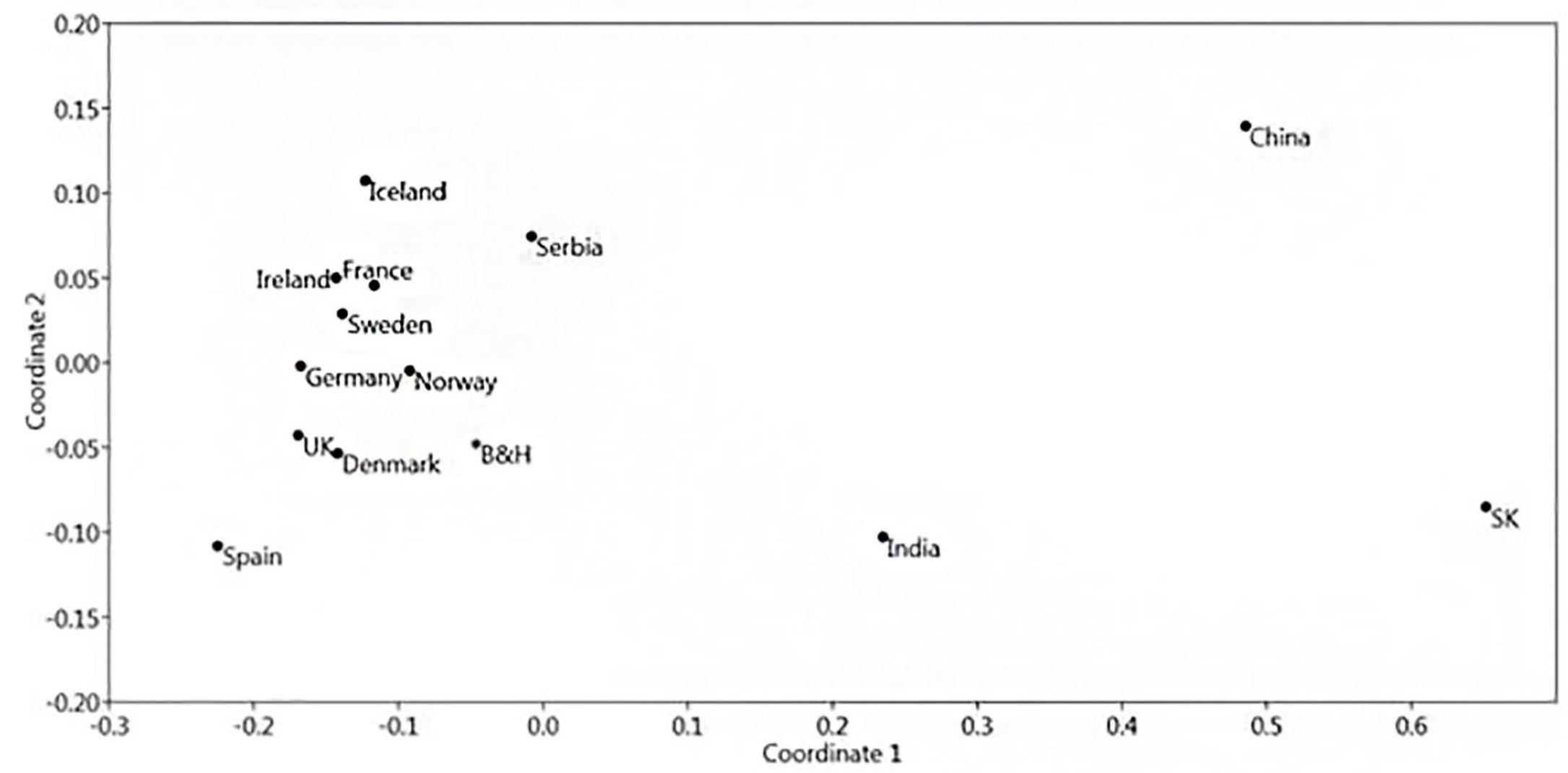

